\title{
Influence of sea-bottom temperature and depth on swept area estimation from trawl surveys
}

\author{
Jure Brčić ${ }^{1}$, Federica Grilli ${ }^{2}$, Antonello Sala ${ }^{2}$ \\ ${ }^{1}$ University of Split, University Department of Marine Studies, Livanjska 5/III, 21000 Split, Croatia. \\ ${ }^{2}$ National Research Council (CNR), Institute of Marine Sciences (ISMAR), Fisheries Section, Largo Fiera della Pesca, \\ 60125 Ancona, Italy. E-mail: a.sala@ismar.cnr.it
}

\begin{abstract}
Summary: The methodological approach to data collection and analysis in Mediterranean bottom trawl surveys has changed considerably since their beginnings in the mid-1980s. The introduction of new technologies in surveys greatly improved knowledge on trawl underwater geometry, but also raised a question on the reliability of the data obtained. The most commonly used trawl monitoring systems in the Mediterranean use the constant speed of sound when calculating horizontal distance from one sensor to another. However, the speed of the sound in seawater is not constant because it depends on water temperature, pressure, and salinity. This is known to affect the performance of the horizontally transmitting sonars, and it is reasonable to assume that unless it is properly compensated for, the readings from trawl monitoring systems can be incorrect, resulting in biased swept area estimates, and hence potentially producing bias in abundance estimates. In the knowledge that speed of sound depends on temperature, salinity and pressure, the Del Grosso (1974) equation was used to calculate the compensation coefficient for a series of theoretical depth and temperature data. A simple model is proposed in the current paper for the manual correction of the horizontal net opening and swept area estimates. Temperature and depth data obtained from the MEDATLAS project are used to show seasonal and spatial variation in the near-bottom speed of sound, and the results demonstrate that, unless compensated for properly, the error in the horizontal net spread ranges from $-1.5 \%$ to $2.9 \%$.
\end{abstract}

Keywords: swept area; bottom trawl survey; net opening; Mediterranean Sea.

Influencia de la temperatura del fondo del mar y profundidad en la estimación del área de barrido en sistemas de arrastre

Resumen: El enfoque metodológico para la recopilación de datos y análisis en estudios de arrastre de fondo del Mediterráneo ha cambiado considerablemente desde sus inicios en los años ochenta. La introducción de nuevas tecnologías en los estudios ha mejorado enormemente el conocimiento de la geometría de los artes de pesca de debajo del agua, pero, al mismo tiempo, surge la pregunta de la fiabilidad de los datos obtenidos. Los sistemas de seguimiento más comúnmente utilizados en los artes en el Mediterráneo usan la velocidad constante del sonido cuando calculan la distancia horizontal de un sensor a otro. Sin embargo la velocidad del sonido en el agua marina no es constante ya que depende de la temperatura del agua, de la presión y la salinidad. Se sabe que esto afecta al rendimiento de los sonares que transmiten en horizontal, y es razonable suponer que si se compensan adecuadamente, las lecturas de los monitores de seguimiento del arte pueden ser incorrectos, dando lugar a estimaciones sesgadas del área barrida por el arte, y en consecuencia potencialmente producir sesgo en bastantes estimaciones. Conociendo que la velocidad del sonido depende de la temperatura, salinidad y presión, se ha usado la ecuación de Del Grosso (1974) para calcular el coeficiente de compensación en series de datos de profundidad teórica y temperatura. A continuación, un modelo simple se ha propuesto en el presente artículo para la corrección manual de la obertura horizontal de la red y estimación del área de barrido. Se han usado los datos de temperatura y profundidad obtenidos del proyecto MEDATLAS para mostrar la variación estacional y espacial en la velocidad del sonido cerca del fondo marino, y los resultados demuestran que, a no ser que se compense adecuadamente, el error en la obertura horizontal de la red varía entre -1.5 a $2.9 \%$.

Palabras clave: área de barrido; estudios de artes de pesca de fondo; obertura de la red; Mar Mediterráneo.

Citation/Cómo citar este artículo: Brčić J., Grilli F., Sala A. 2014. Influence of sea-bottom temperature and depth on swept area estimation from trawl surveys. Sci. Mar. 78(1): 135-142. doi: http://dx.doi.org/10.3989/scimar.03819.24A

Editor: P. Sartor.

Received: January 25, 2013. Accepted: October 28, 2013. Published: February 21, 2014

Copyright: (C) 2014 CSIC. This is an open-access article distributed under the Creative Commons Attribution-Non Commercial Lisence (by-nc) Spain 3.0. 


\section{INTRODUCTION}

Effective and successful fisheries management depends greatly on reliable monitoring of fish stocks (Godø 1998, Legović et al. 2010). For the purpose of monitoring demersal fish stocks, bottom trawl surveys are most commonly used (Bertrand et al. 2002, Dremière et al. 1999, Fiorentini et al. 1999). As trawl efficiency is constantly improving and fishing practice is continuously changing (Lucchetti and Sala 2012, Eigaard et al. 2011, Lucchetti and Sala 2010, Fiorentini et al. 2004), this type of standardized survey provides reliable data for describing and quantifying changes in the exploited fish populations (Jukic-Peladic et al. 2001). The most common method used for relative biomass estimation is the swept area method (Saville 1977, Sparre and Venema 1998). A swept area represents the area covered by the trawl while towing and can be calculated by multiplying trawl wing spread (horizontal net opening) by distance covered, while gear is in contact with the seabed. Relative biomass or catch per unit of area is then calculated by dividing catch by swept area (Sparre and Venema 1998) and it is usually expressed in terms of density (e.g. $\mathrm{kg} \mathrm{km}^{-2}$ ). These estimates depend highly on the correct calculation of the swept area, which can easily be miscalculated if the effective tow duration or wing spread are inaccurate (Godø and Engås 1989). The introduction of wireless acoustic trawl monitoring systems in demersal trawl surveys made it possible to monitor trawl performance in real time (Sala et al. 2009, Prat et al. 2008), generally improving catch per unit of effort and swept area estimates (Zimmermann et al. 2003). The most common net trawl measurement systems used in the central Mediterranean (SCANMAR pers. comm.), use the constant speed of sound of $1500 \mathrm{~m} / \mathrm{s}$ in their algorithms when calculating the distance between two sensors.

However, the speed of sound in seawater is not constant because it depends on water temperature, pressure, and salinity (Chen and Millero 1977, Coppens 1981, Del Grosso 1974, Leroy et al. 2008, Wong and Zhu 1995). Hall (2000), for example, noted that the speed of sound in water might change by approximately $3 \mathrm{~m}$ $\mathrm{s}^{-1}$ per $1^{\circ} \mathrm{C}$. This is known to affect the performance of the horizontally transmitting sonars (Simmonds and MacLennan 2005), and it is reasonable to assume that unless it is properly compensated for, the readings from trawl monitoring systems can be incorrect, resulting in biased swept area estimates. Nowadays, some manufacturers of advanced products for the fishing fleet (e.g. sonars, echo sounders and gear monitoring instrumentation) are designing technology to compensate for this variation and thus ensuring accurate and reliable measured data. By logging data from the combined depth/temperature sensor during the shooting of the equipment, an accurate temperature profile is generated and modern equipment with proper input can automatically compensate for any temperature changes. In this paper we assessed the influence of the seawater temperature and depth on the speed of sound in the central Mediterranean. Moreover, we provided a simple model, which is presented as a valid alternative to the application of the complex formulae reported by Chen and Millero (1977), Coppens (1981), Del Grosso (1974) and Wong and Zhu (1995) for manual correction of horizontal net opening and more precise swept area estimates. The new equation is proposed for the calculation of sound speed in seawater as a function of temperature, and depth and it is of polynomial form with three terms, which is a substantial reduction in complexity compared with the more complex equations using pressure that need to be calculated according to depth and location.

\section{MATERIALS AND METHODS}

\section{Mediterranean trawl survey (MEDITS)}

Bottom trawl surveys in the central Mediterranean have been performed regularly since 1985 (Bertrand et al. 2002), with the MEDITS project being the most important one. Sampling in this survey covers almost all trawlable areas from 10 to $800 \mathrm{~m}$ (Bertrand et al. 2002) following a depth-stratified regime with strictly defined limits (10-50 m, 50-100 m, 100-200 m, 200$500 \mathrm{~m}$ and $500-800 \mathrm{~m}$ ). A standard tow lasts $30 \mathrm{~min}-$ utes for depths up to $200 \mathrm{~m}$ and 60 minutes for depths over $200 \mathrm{~m}$. Sampling vessels are equipped with both data loggers, that record water temperature and depth at the trawl level, and acoustic net monitoring systems (Bertrand et al. 2002).

\section{Calculation of the sound compensation coefficient (SCC)}

A number of equations for this purpose were developed in the second half of the twentieth century. Synoptical reviews of the available equations have been published by Dushaw et al. (1993) and Leroy (2001). The equation developed by Chen and Millero (1977) is considered an international standard for the calculation of the speed of sound in seawater. An alternative equation, which has a more restricted range of validity but is preferred by some authors (Dushaw et al. 1993, Meinen and Watts 1997, Speisberger and Metzger 1991, Speisberger 1993, Pike and Beiboer 1993), is the Del Grosso equation (Del Grosso 1974). In this study we have used the Del Grosso equation since it is implemented in most trawl monitoring systems used in the MEDITS survey (SCANMAR pers. comm.). Wong and Zhu (1995) reformulated this equation for the new 1990 International Temperature Scale and their version is:

$c(S, T, P)=C_{000}+\Delta C_{T}(T)+\Delta C_{S}(S)+\Delta C_{P}(P)+\Delta C_{S T P}(S, T, P)$

where speed of sound in seawater $\left(c\left[\mathrm{~m} \mathrm{~s}^{-1}\right]\right)$ is a function of temperature $\left(T\left[{ }^{\circ} \mathrm{C}\right]\right)$, salinity $(S[\mathrm{ppt}])$ and pressure $\left(P\left[\mathrm{~kg} \mathrm{~cm}^{-2}\right]\right)$. Since Equation (1) uses pressure instead of depth, conversion had to be made according to Leroy and Parthiot (1998):

$$
P(Z, \Phi)=h(Z, \Phi)-h_{0} Z
$$


where $Z$ is the depth in metres, $\Phi$ is the latitude in radians, $h$ is the pressure in $\mathrm{MPa}$ (relative to the atmospheric pressure), and $h_{0} Z$ is the corrective term that has to be subtracted from the value. For the Mediterranean Sea, a fixed latitude of $36^{\circ}$ and the following corrective term were used:

$$
h_{0} Z=-8.5 \times 10^{-6} Z+1.4 \times 10^{-9} Z^{2}
$$

Equations (1) and (2) are detailed in the Annex 1.

The correct horizontal net openings can be calculated asfollowsfrom the datarecordedbytheacoustictrawlmonitoring systems, which use the constant speed of sound:

$$
H N O_{c}=\mathrm{SCC} \cdot H N O_{u}
$$

where $H N O_{c}[\mathrm{~m}]$ and $H N O_{u}[\mathrm{~m}]$ are the compensated and the uncompensated horizontal net opening, respectively, and the SCC represents the ratio of the real speed of sound (associated with a given depth, salinity and water temperature values) and the constant speed of $1500 \mathrm{~m} \mathrm{~s}^{-1}$ :

$$
\mathrm{SCC}=c(S, T, P) / c_{\text {cost }}
$$

Since salinity observations during trawl surveys are often unavailable, in agreement with Vargas-Yáñez et al. (2012) and Adani et al. (2011), a constant value of $38 \mathrm{ppt}$ was assumed. Such fixed value of salinity together a series of theoretical sea depth and water temperature combinations have been used in the Eqs. (1)-(5) for the calculation of a sound compensation coefficients (SCC) dataset.
A generalized linear model (GLM) was applied to this dataset in order to provide coefficient estimates and summary statistics for the prediction regression models of the SCC parameter in function of the independent parameters sea water temperature (SWT) and bottom sea depth (BSD). All the calculations were performed with the use of the SPSS software package.

\section{Spatial data interpolation}

SCC was calculated using the BSD and bottom SWT data obtained from MEDATLAS II project (MEDAR Group 2002). It was gridded with data interpolating variational analysis (DIVA, http://modb.oce. ulg.ac.be/projects/1/diva) and mapped with the Ocean Data View 4 software package (ODV) (Schlitzer 2011). A polynomial regression (e.g. simple planar surface) gridding method was used to graphically represent influence of temperature and bottom depth on SCC using the Surfer 9 software package (Golden Software Inc., Golden, Colorado, USA), while the graphical representation of the seasonal variations of the speed of sound for different depth strata was produced using the lattice package (Sarkar 2008) in R software (R Core Team 2012).

\section{RESULTS}

In Table 1 we reported the SCC calculated with Equations (1)-(5) for SWT ranging from $0^{\circ} \mathrm{C}$ to $30^{\circ} \mathrm{C}$ at BSD from 0 to $1000 \mathrm{~m}$. The variability of the $S C C$ as a function of SWT and BSD is shown in Figure 1.

\begin{tabular}{|c|c|c|c|c|c|c|c|c|c|c|c|c|c|c|c|c|c|c|}
\hline SWT & & & & & & & & & & & & & & & & & & \\
\hline$\left({ }^{\circ} \mathrm{C}\right)$ & 0 & 5 & 10 & 20 & 30 & 40 & 50 & 75 & 100 & 150 & 200 & 250 & 300 & 400 & 500 & 600 & 800 & 1000 \\
\hline 0 & 0.969 & 969 & 969 & 969 & 0.969 & 969 & 0.969 & 0.970 & 0.970 & 0.970 & 0.971 & 0.971 & 0.972 & 0.973 & 0.974 & 0.975 & 0.977 & 0.980 \\
\hline 1 & 0.972 & 0.972 & 0.972 & 0.972 & 0.972 & 0.972 & 0.972 & 0.973 & 0.973 & 0.973 & 0.974 & 0.974 & 0.975 & 0.976 & 0.977 & 0.978 & 0.980 & 0.983 \\
\hline 2 & 0.975 & 0.975 & 0.975 & 0.975 & 0.975 & 0.975 & 0.975 & 0.975 & 0.976 & 0.976 & 0.977 & 0.977 & 0.978 & 0.979 & 0.980 & 0.981 & 0.983 & 0.986 \\
\hline 3 & 0.977 & 0.978 & 0.978 & 0.978 & 0.978 & 0.978 & 0.978 & 0.978 & 0.979 & 0.979 & 0.980 & 0.980 & 0.981 & 0.982 & 0.983 & 0.984 & 0.986 & 0.988 \\
\hline 4 & 0.980 & 0.980 & 0.980 & 0.980 & 0.981 & 0.981 & 0.981 & 0.981 & 0.981 & 0.982 & 0.982 & 0.983 & 0.984 & 0.985 & 0.986 & 0.987 & 0.989 & 0.991 \\
\hline 5 & 0.983 & 0.983 & 0.983 & 0.983 & 0.983 & 0.983 & 0.984 & 84 & 0.984 & 0.985 & 0.985 & 0.986 & 0.986 & 0.987 & 0.988 & 0.990 & 0.992 & 0.994 \\
\hline 6 & 0.986 & 0.986 & 86 & 0.986 & 0.986 & 986 & 0.986 & 0.986 & .987 & 0.987 & 0.988 & 0.988 & 0.989 & 0.990 & 0.991 & 92 & 0.994 & 0.997 \\
\hline 7 & 0.988 & 0.988 & 0.988 & 0.988 & 0.989 & 0.989 & 0.989 & 0.989 & 989 & 0.990 & 0.990 & 0.991 & 0.992 & 0.993 & 94 & 0.995 & 0.997 & 99 \\
\hline 8 & 0.991 & 0.991 & 0.991 & 0.991 & 0.991 & 0.991 & 0.991 & 0.992 & .992 & 0.992 & 0.993 & 0.993 & 0.994 & 0.995 & 0.996 & 0.997 & .000 & 1.002 \\
\hline 9 & 0.993 & 0.993 & 0.993 & 0.993 & 0.994 & 0.994 & 0.994 & 0.994 & 0.994 & 0.995 & 0.995 & 0.996 & 0.997 & 0.998 & 0.999 & 1.000 & 1.002 & 1.004 \\
\hline 10 & 0.996 & 0.996 & 0.996 & 0.996 & 0.996 & 0.996 & 0.996 & 0.996 & 0.997 & 0.997 & 0.998 & 0.998 & 0.999 & 1.000 & 1.001 & 1.002 & 1.004 & 1.007 \\
\hline 11 & 0.998 & 0.998 & 0.998 & 0.998 & 0.998 & 0.998 & 0.999 & 0.999 & 0.999 & 1.000 & 1.000 & 1.001 & 1.001 & 1.002 & 1.003 & 1.005 & 1.007 & 1.009 \\
\hline 12 & 1.000 & 1.000 & 1.000 & 1.000 & 1.001 & 1.001 & 1.001 & 1.001 & 1.001 & 1.002 & 1.002 & 1.003 & 1.004 & 1.005 & 1.006 & 1.007 & 1.009 & 1.011 \\
\hline 13 & 1.003 & 1.003 & 1.003 & 1.003 & 1.003 & 1.003 & 1.003 & 1.003 & 1.004 & 1.004 & 1.005 & 1.005 & 1.006 & 1.007 & 1.008 & 1.009 & 1.011 & 1.014 \\
\hline 14 & 1.005 & 1.005 & 1.005 & 1.005 & 1.005 & 1.005 & 1.005 & 1.006 & 1.006 & 1.006 & 1.007 & 1.007 & 1. & 1.009 & 1.010 & 11 & 014 & 1.016 \\
\hline 15 & 1.007 & 1.007 & 1.007 & 1.007 & 1.007 & 1.007 & 1.007 & 1.008 & 1.008 & 1.008 & 1.009 & 1.010 & 1. & 1.011 & 1.012 & 3 & 1.016 & 1.018 \\
\hline 16 & 1.009 & 1.009 & 1.009 & 1.009 & 1.009 & 1.009 & 1.009 & 1.010 & 1.010 & 1.011 & 1.011 & 1.012 & 1.012 & 1.013 & 1.014 & 15 & 1.018 & 1.020 \\
\hline 17 & 1.011 & 1.011 & 1.011 & 1.011 & 1.011 & 1.011 & 1.011 & 1.012 & 1.012 & 1.013 & 1.013 & 1.014 & 1.014 & 1.015 & 1.016 & 1.018 & 1.020 & 1.022 \\
\hline 18 & 1.013 & 1.013 & 1.013 & 1.013 & 1.013 & 1.013 & 1.013 & 1.014 & 1.014 & 1.014 & 1.015 & 1.016 & 1.016 & 1.017 & 1.018 & 1.019 & 1.022 & 1.024 \\
\hline 19 & 1.015 & 1.015 & 1.015 & 1.015 & 1.015 & 1.015 & 1.015 & 1.016 & 1.016 & 1.016 & 1.017 & 1.017 & 1.018 & 1.019 & 1.020 & 1.021 & 1.024 & 1.026 \\
\hline 20 & 1.017 & 1.017 & 1.017 & 1.017 & 1.017 & 1.017 & 1.017 & 1.017 & 1.018 & 1.018 & 1.019 & 1.019 & 1.020 & 1.021 & 1.022 & 1.023 & 1.025 & 1.028 \\
\hline 21 & 1.018 & 1.018 & 1.018 & 1.019 & 1.019 & 1.019 & 1.019 & 1.019 & 1.019 & 1.020 & 1.021 & 1.021 & 1.022 & 1.023 & 1.024 & 1.025 & 1.027 & 1.029 \\
\hline 22 & 1.020 & 1.020 & 1.020 & 1.020 & 1.020 & 1.021 & 1.021 & 1.021 & 1.021 & 1.022 & 1.022 & 1.023 & 1.023 & 1.025 & 1.026 & 1.027 & 1.029 & 1.031 \\
\hline 23 & 1.022 & 1.022 & 1.022 & 1.022 & 1.022 & 1.022 & 1.022 & 1.023 & 1.023 & 1.023 & 1.024 & 1.025 & 1.025 & 1.026 & 1.027 & 1.028 & 1.031 & 1.033 \\
\hline 24 & 1.023 & 1.024 & 1.024 & 1.024 & 1.024 & 1.024 & 1.024 & 1.024 & 1.025 & 1.025 & 1.026 & 1.026 & 1.027 & 1.028 & 1.029 & 1.030 & 1.032 & 1.034 \\
\hline 25 & 1.025 & 1.025 & 1.025 & 1.025 & 1.025 & 1.026 & 1.026 & 1.026 & 1.026 & 1.027 & 1.027 & 1.028 & 1.028 & 1.029 & 1.031 & 1.032 & 1.034 & 1.036 \\
\hline 26 & 1.027 & 1.027 & 1.027 & 1.027 & 1.027 & 1.027 & 1.027 & 1.027 & 1.028 & 1.028 & 1.029 & 1.029 & 1.030 & 1.031 & 1.032 & 1.033 & 1.035 & 1.038 \\
\hline 27 & 1.028 & 1.028 & 1.028 & 1.028 & 1.028 & 1.029 & 1.029 & 1.029 & 1.029 & 1.030 & 1.030 & 1.031 & 1.031 & 1.032 & 1.034 & 1.035 & 1.037 & 1.039 \\
\hline 28 & 1.030 & 1.030 & 1.030 & 1.030 & 1.030 & 1.030 & 1.030 & 1.030 & 1.031 & 1.031 & 1.032 & 1.032 & 1.033 & 1.034 & 1.035 & 1.036 & 1.038 & 1.040 \\
\hline 29 & 1.031 & 1.031 & 1.031 & 1.031 & 1.031 & 1.031 & 1.032 & 1.032 & 1.032 & 1.033 & 1.033 & 1.034 & 1.034 & 1.035 & 1.036 & 1.038 & 1.040 & 1.042 \\
\hline 30 & 1.032 & 1.032 & 1.033 & 1.033 & 1.033 & 1.033 & 1.033 & 1.033 & 1.033 & 1.034 & 1.035 & 1.035 & 1.036 & 1.037 & 1.038 & 1.039 & 1.041 & 1.043 \\
\hline
\end{tabular}

Table 1. - Sound compensation coefficient (SCC) calculated with the Del Grosso (1974) equation for different bottom sea depth (BSD) and sea water temperature (SWT) combinations. 


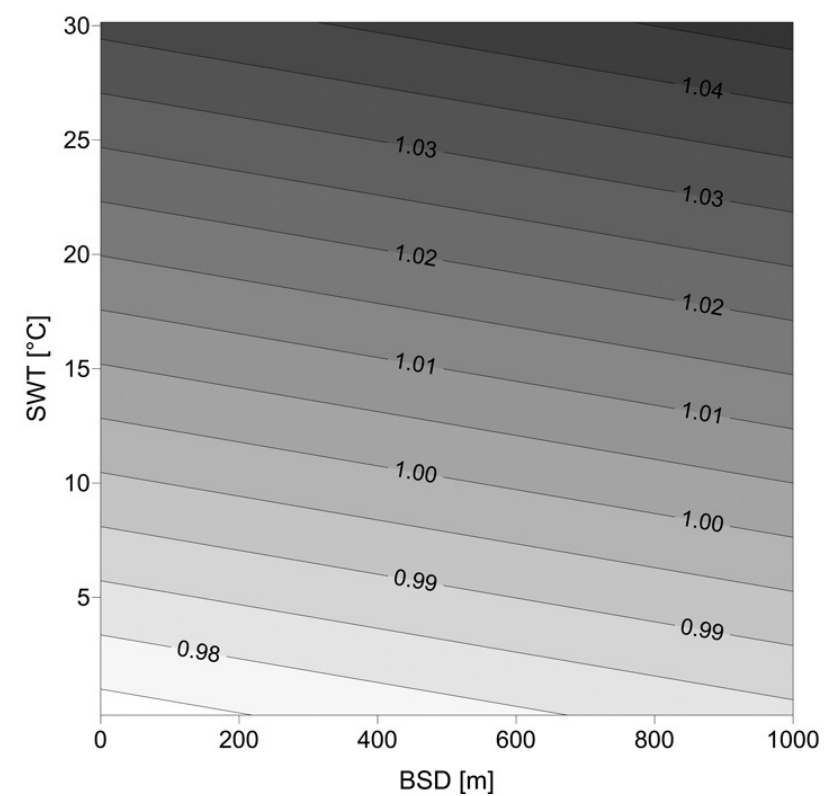

Fig. 1. - Isopleth representation of Sound Compensation Coefficient (SCC) for different sea water temperature (SWT) and sea bottom sea depth (BSD) combinations.

Using the bottom SWT and depth data from the MEDATLAS II project (MEDAR Group 2002), the seasonal distribution of the speed of sound, $c(S, T, P)$, was calculated for each depth stratum (Fig. 2). Both the high variability in near bottom temperatures, related to the natural temperature fluctuations, and the large depth range in the Mediterranean, resulted in large seasonal differences in the distribution of the speed of sound. Values of the speed of sound in the sea water ranged from $1478 \mathrm{~m} \mathrm{~s}^{-1}$ in the winter period to 1544 $\mathrm{m} / \mathrm{s}$ in the summer period (Fig. 2). Consequently, SCC (i.e. ratio of the real speed of sound and a constant speed of $1500 \mathrm{~m} \mathrm{~s}^{-1}$ ) ranged between 0.985 and 1.029 and unless properly compensated as per Equation 4, the error in the measured horizontal net spread might range from -1.47 to $2.93 \%$.During the summer season, when bottom trawl surveys are usually conducted, low temperatures and high pressures in deeper water resulted in lower sound speeds than in shallower areas (10-50 m), resulting in a spatial bias (Fig. 3). Sound speeds were also lower than $1500 \mathrm{~m} \mathrm{~s}^{-1}$ in the winter season in the shallow areas (e.g. the North Adriatic Sea), resulting in a source of temporal bias (Fig. 3).

The GLM routines applied to these data provided a suitable prediction model for the SCC (Sig. <0.001; Table 2), which is presented as a valid alternative to the application of the complex formulae reported from Equations 1 to 5. Furthermore, the proposed equation agrees more than $99.8 \%$ with the values obtained by the complex Del Grosso (1974) reference equation. As can be seen from the output results of the multiple regression analysis reported in Table 2, the fit of the models (R-square) indicates that more than $98 \%$ of the variation in SCC can be accounted for by the SWT and the BSD. Therefore, the use of further variables would not have substantially improved the approximation of data, so the multiple regression relationship is:

$$
\begin{aligned}
\mathrm{SCC}= & 0.97291+0.02111 \cdot(\mathrm{SWT} / 10)+ \\
& +0.01098 \cdot(\mathrm{BSD} / 1000)
\end{aligned}
$$

An increase in the SWT or the BSD resulted in a general increase in the SCC. However, the SCC seems

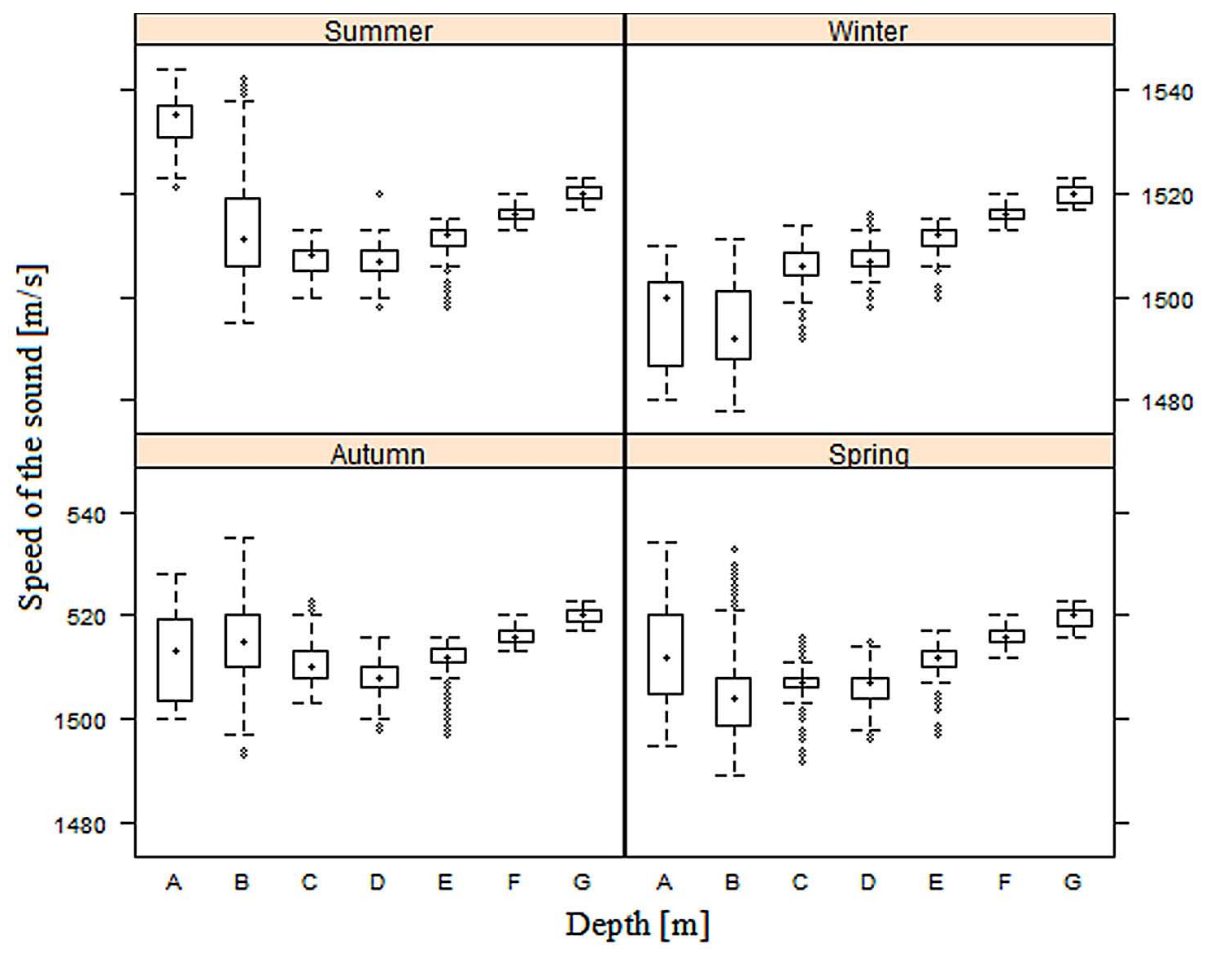

Fig. 2. - Seasonal variations of the calculated Speed of the sound [m s${ }^{-1}$ ] from different depth strata (A: 0-10 m; B: 11-50 m; C: $51-100 \mathrm{~m}$; D: 101-200 m; E: 201-500 m; F: 501-800 m; G: 801-1000 m). Strata are defined following the MEDITS sampling strategy (Bertrand et al. 2002). 

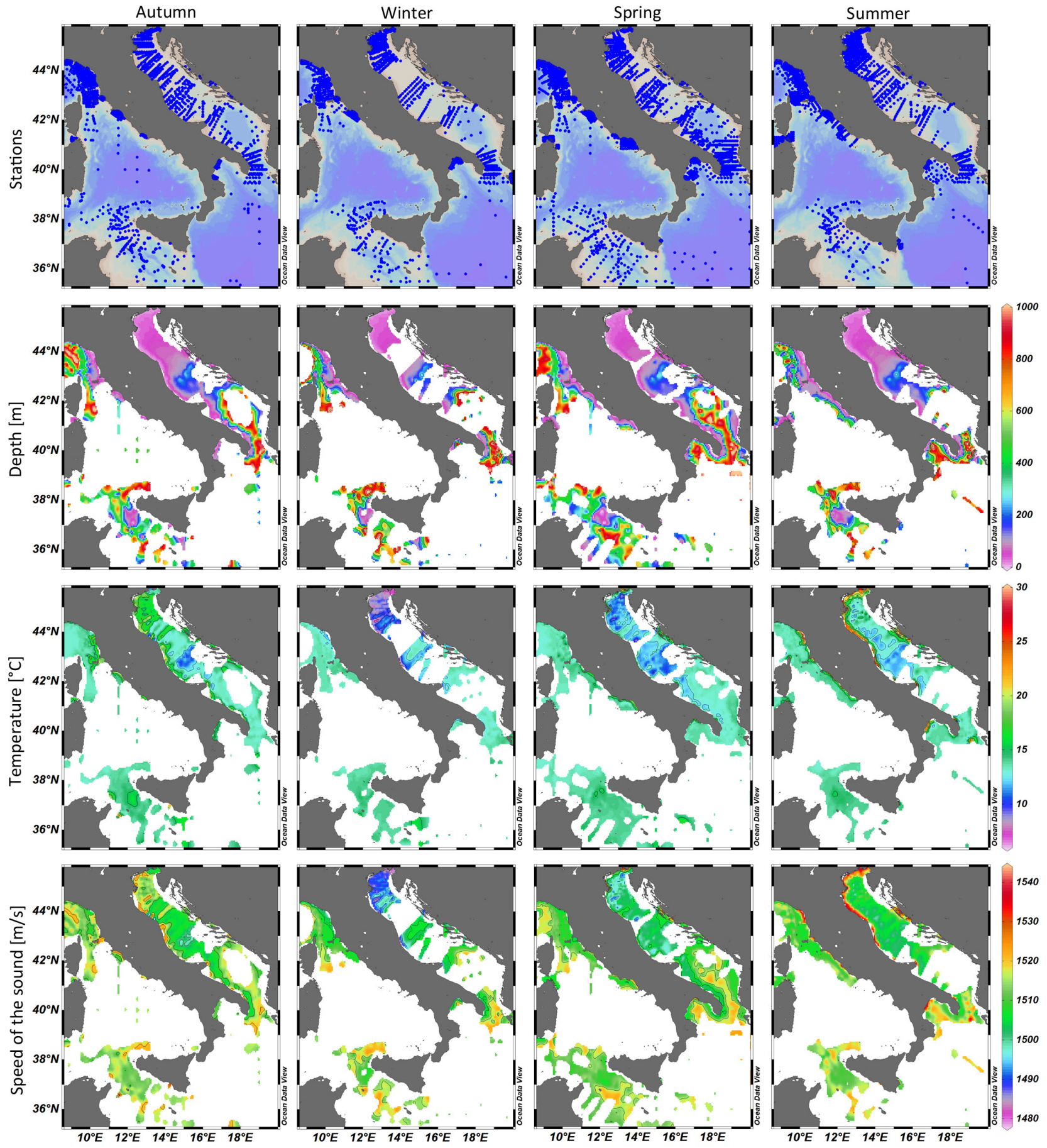

Fig. 3. - Temperature and depth data of stations from MEDATLAS project (MEDAR Group 2002) were used to calculate the near bottom speed of the sound using the Del Grosso (1974) equation. Seasonal and spatial variation in the temperature, depth and near bottom speed of the sound were gridded with Data Interpolating Variational Analysis (DIVA, http://modb.oce.ulg.ac.be/projects) and mapped with Ocean Data View 4 software package (Schlitzer 2011).

Table 2. - Estimated coefficients (B) and Standard Error (Std. Error) of Generalized Linear Model (GLM) routines, applied to the dependent measure Sound Compensation Coefficient (SCC) in function of the independent parameters sea water temperature (SWT) and bottom sea depth (BSD). ANOVA results: degree of freedoms (DF), R-square $\left(\mathrm{R}^{2}\right)$, F statistic (F) and Model significance (Mod. Sig.) are also reported.

\begin{tabular}{|c|c|c|c|c|c|c|c|c|}
\hline \multirow[b]{2}{*}{ Parameter } & \multicolumn{4}{|c|}{ Estimated coefficients } & \multicolumn{4}{|c|}{ ANOVA } \\
\hline & B & Std. Error & $\mathrm{t}$ & Sig. & DF & $\mathrm{R}^{2}$ & F & Mod. Sig. \\
\hline Constant & 0.97291 & 0.00018 & 5364.19 & 0.000 & & & & \\
\hline SWT & 0.02111 & 0.00009 & 222.52 & 0.000 & $(2,557)$ & 0.989 & 25457.9 & 0.000 \\
\hline BSD & 0.01098 & 0.00029 & 37.44 & 0.000 & & & & \\
\hline
\end{tabular}

GLM: SCC $=0.97291+0.02111 \cdot(\mathrm{SWT} / 10)+0.01098 \cdot(\mathrm{BSD} / 1000)$ 
more sensitive to changes of SWT than BSD, as shown in Figure 1 and in the parameter coefficients presented in Table 2.

\section{DISCUSSION}

In this study, we have shown how readings from an acoustic trawl monitoring system can be biased to changes in near-bottom water temperature. The results have shown that values of horizontal net opening can be both over- and underestimated, depending on the season and area of the survey. Depth strata between 10 and $50 \mathrm{~m}$ have shown the largest variation in speed of sound, which can be explained by the presence of a well-developed thermocline in that layer (Artegiani et al. 1997). The highest seasonal variations in the speed of the sound were observed in northern Adriatic Sea, which is an area with shallow waters with the highest seasonal thermal gradient (Russo and Artegiani 1996). These results emphasize the importance of compensating for the influence of temperature and depth effect on the speed of sound during the trawl survey, assuming that both temperature and depth data are available. Similar results were obtained by Kotwicki et al. (2011), who instead of Del Grosso (1974) used the formula of Coppens (1981) for the accurate estimate of the speed of sound. Their results have shown that after compensating for the temperature effect, the original measured swept area was overestimated for all tows. The new area swept estimates indicate that the expected corrections will range between $-4 \%$ and $-1 \%$.

Traditionally, changes in sampling procedures and equipment used in bottom trawl surveys are avoided because of the concern that changes could invalidate survey time series (Godø 1998). Although the methodology of bottom trawl surveys in the central Mediterranean has changed considerably since the mid-1980s (Bertrand et al. 2002), standardizations have become more rigorous (ICES 2009). Our results suggest that every change (Godø 1998) in survey methodology, no matter how trivial it may seem to be (e.g. transfer from one trawl monitoring system to another, or from an older to a newer one), must be examined thoroughly to make sure that no bias is being overlooked.

Zimmermann et al. (2003) described how technical improvements in survey methods can affect fish abundance estimation. They analysed data from U.S. bottom trawl surveys before and after the introduction of new technical equipment, and concluded that changes in abundance indices of some taxa are more likely to be the result of improvements in trawling methods than the real change in abundance. As technology advances it is reasonable to assume that future survey trawls will be equipped with numerous sensors of far better precision then the ones currently being used, providing us with much better net performance monitoring. This is unavoidable, and in many ways desirable but it should be implemented with great caution, because if the goal of the surveys is to monitor changes in abundance of exploited species over a long period of time, all sources of bias must be identified. In our case, influence of temperature and depth on the speed of sound and later on net spread values can easily be retroactively corrected with the proposed model (see Eq. 6), especially knowing that trawl surveys in the study area have been equipped with autonomous temperature and depth recorder since 1998 (Bertrand et al. 2002).

\section{ACKNOWLEDGEMENTS}

This work was funded by the Flagship Project RITMARE "The Italian Research for the Sea", coordinated by the Italian National Research Council and funded by the Italian Ministry of Education, University and Research within the 2011-2013 National Research Programme. We would like to thank Joana d'Arc Prat Farran (Universitat Politècnica de Catalunya, Spain) for helpful to translate the abstract into Spanish. Finally, we are also grateful to the editor and the reviewers for their comments, which we feel have improved our manuscript.

\section{FUTURE WORKS}

In order to prove and support the theoretical statements and calculations provided in the current paper, direct observations of sound-compensated and sounduncompensated horizontal net openings at different sea water temperatures, salinities and depths have been planned for the forthcoming sea cruises in 2014 within the RITMARE project.

\section{REFERENCES}

Adani M., Dobricic S.,Pinardi N. 2011. Quality Assessment of a 19852007 Mediterranean Sea Reanalysis. J. Atmos. Ocean. Tech. 28: 569-589. http://dx.doi.org/10.1175/2010JTECHO798.1

Artegiani A., Bregant D., Paschini E., Pinardi N., Raicich F., Russo A. 1997. The Adriatic Sea general circulation. Part I: Air-sea interactions and water mass structure. J. Phys. Oceanogr. 27: 14921514. http://dx.doi.org/10.1175/1520-0485(1997)027<1492:TA $\mathrm{SGCP}>2.0 . \mathrm{CO} ; 2$

Bertrand J.A., Gil de Sola L., Papaconstantinou, C., Relini, G., Souplet, A. 2002. The general specifications of the Medits surveys. Sci. Mar. 66 (Suppl. 2): 9-17. http://dx.doi.org/10.3989/scimar.2002.66s29

Chen C.-T., Millero F.J. 1977. Speed of sound in seawater at high pressures. J. Acoust. Soc. Am. 62: 1129-1135. http://dx.doi.org/10.1121/1.381646

Coppens A.B. 1981. Simple equations for the speed of sound in Neptunian waters. J. Acoust. Soc. Am. 69: 862-863. http://dx.doi.org/10.1121/1.385486

Del Grosso V.A. 1974. New equation for the speed of sound in natural waters (with comparisons to other equations). J. Acoust. Soc. Am. 56: 1084-1091. http://dx.doi.org/10.1121/1.1903388

Dremière P.Y., Fiorentini L., Cosimi G., Leonori I., Sala A., Spagnolo, A., 1999. Escapement from the main body of the bottom trawl used for the Mediterranean International Trawl Survey (MEDITS). Aquat. Living Resour. 12(3): 207-217. http://dx.doi.org/10.1016/S0990-7440(00)88471-5

Dushaw B.D., Worcester P.F., Cornuelle B.D., Howe B.M. 1993. On equations for the speed of sound in sea water. J. Acoust. Soc. Am. 93(1): 255-275. http://dx.doi.org/10.1121/1.405660

Eigaard O.R., Rihan D., Graham N., Sala A., Zachariassen K. 2011. Improving fishing effort descriptors: Modelling engine power and gear-size relations of five European trawl fleets. Fish. Res. 110: 39-46. http://dx.doi.org/10.1016/j.fishres.2011.03.010

Fiorentini L., Dremière P.Y., Leonori I., Sala A., Palumbo V. 1999. Efficiency of the bottom trawl used for the Mediterranean International Trawl Survey (MEDITS). Aquat. Living Resour. 12(3): 187-205. http://dx.doi.org/10.1016/S0990-7440(00)88470-3

Fiorentini L., Sala A., Hansen K., Cosimi G., Palumbo V. 2004. Comparison between model testing and full-scale trials of new 
trawl design for Italian bottom fisheries. Fish. Sci. 70: 349-359. http://dx.doi.org/10.1111/j.1444-2906.2004.00813.x

Godø O.R. 1998. What can technology offer the future fisheries scientist - Possibilities for obtaining better estimates of stock abundance by direct observations. J. Northwest Atl. Fish. Sci. 23: 105-131. http://dx.doi.org/10.2960/J.v23.a7

Godø O.R., Engås A. 1989. Swept area variation with depth and its influence on abundance indices of groundfish from trawl surveys. J. Northwest Atl. Fish. Sci. 9: 133-139. http://dx.doi.org/10.2960/J.v9.a12

Hall J.B. 2000. Principles of naval weapons systems. Kendall/Hunt Publishing, $358 \mathrm{pp}$.

ICES. 2009. Report of the Study Group on Survey Trawl Standardisation (SGSTS), by correspondence. ICES CM 2009/FTC:09, $127 \mathrm{pp}$.

Jukic-Peladic S., Vrgoc N., Krstulovic-Sifner S., Piccinetti C., Piccinetti-Manfrin G., Marano G., Ungaro N. 2001. Long-term changes in demersal resources of the Adriatic Sea: comparison between trawl surveys carried out in 1948 and 1998. Fish. Res. 53: 95-104. http://dx.doi.org/10.1016/S0165-7836(00)00232-0

Kotwicki S., Martin M.H., Laman E.A. 2011. Improving area swept estimates from bottom trawl surveys. Fish. Res. 110: 198-206. http://dx.doi.org/10.1016/j.fishres.2011.04.007

Legović T., Klanjšček J., Geček S. 2010. Maximum sustainable yield and species extinction in ecosystems. Ecol. Model. 221: 1569-1574. http://dx.doi.org/10.1016/j.ecolmodel.2010.03.024

Leroy C.C. 2001. The speed of sound in pure and Neptunian water. Handbook of elastic properties of solids, liquids, and gases. Academic, New York, Vol. IV, Chap. 2: 23-81.

Leroy C.C., Parthiot F. 1998. Depth-pressure relationship in the oceans and seas. J. Acoust. Soc. Am. 103: 1346-1352. http://dx.doi.org/10.1121/1.421275

Leroy C.C., Robinson S.P., Goldsmith M.J. 2008. A new equation for the accurate calculation of sound speed in all oceans J. Acoust. Soc. Am. 124(5): 2774-2782. http://dx.doi.org/10.1121/1.2988296

Lucchetti A., Sala A. 2010. An overview of loggerhead sea turtle (Caretta caretta) bycatch and technical mitigation measures in the Mediterranean Sea. Rev. Fish Biol. Fisher., 20(2), 141-161. http://dx.doi.org/10.1007/s11160-009-9126-1

Lucchetti A., Sala A. 2012. Impact and performance of Mediterranean fishing gear by side-scan sonar technology. Can. J. Fish. Aquat. Sci. 69: 1806-1816. http://dx.doi.org/10.1139/f2012-107

MEDAR Group. 2002. MEDATLAS/2002 database. Mediterranean and Black Sea database of temperature salinity and biochemical parameters. Climatological Atlas. IFREMER Edition (4 Cdroms).

Meinen C.S., Watts D.R. 1997. Further evidence that the soundspeed algorithm of Del Grosso is more accurate than that of
Chen and Millero. J. Acoust. Soc. Am. 102(4): 2058-2062. http://dx.doi.org/10.1121/1.419655

Pike J.M., Beiboer F.L. 1993. A comparison between algorithms for the speed of sound in seawater. The Hydrographic Society, Special Publication no. 34

Prat J., Antonijuan J., Folch A., Sala A., Lucchetti A., Sardà F., Manuel A. 2008. A simplified model of the interaction of the trawl warps, the otterboards and netting drag. Fish. Res. 94: 109-117. http://dx.doi.org/10.1016/j.fishres.2008.07.007

R Core Team 2012. R: A language and environment for statistical computing. R Foundation for Statistical Computing, Vienna, Austria. URL http://www.R-project.org/

Russo A., Artegiani A. 1996. Adriatic Sea hydrography. Sci. Mar. 60(Suppl. 2): 33-43.

Sala A., Prat J., Antonijuan J., Lucchetti A. 2009. Performance and impact on the seabed of an existing- and an experimentalotterboard: Comparison between model testing and full-scale sea trials. Fish. Res. 100: 156-166. http://dx.doi.org/10.1016/j.fishres.2009.07.004

Sarkar D. 2008. Lattice: multivariate data visualization with R. Springer, New York. ISBN 978-0-387-75968-5.

Saville A. 1977. Survey methods of appraising fishery resources. FAO Fish. Tech. Pap. 171: 76

Schlitzer R. 2011. Ocean Data View. http://odv.awi.de

Simmonds E.J., MacLennan D.N. 2005. Fisheries Acoustics: Theory and Practice, 2nd edn. Blackwell Science, London, $437 \mathrm{pp}$. http://dx.doi.org/10.1002/9780470995303

Sparre P., Venema S.C. 1998. Introduction to tropical fish stock assessment. Part 1. Manual. FAO Fish. Tech. Pap. No. 306.1, Rev. 2, 407 pp.

Speisberger J.L. 1993. Is Del Grosso's sound-speed algorithm correct? J. Acoust. Soc. Am. 93(4): 2235-2237. http://dx.doi.org/10.1121/1.406686

Speisberger J.L., Metzger K. 1991. New estimates of sound speed in water. J. Acoust. Soc. Am. 89(4): 1697-1700. http://dx.doi.org/10.1121/1.401002

Vargas-Yáñez M., Mallard, E., Rixen, M., Zunino, P., García-Martínez, M.C., Moya, F. 2012. The effect of interpolation methods in temperature and salinity trends in the Western Mediterranean. Medit. Mar. Sci., 13/1: 118-125.

Wong G.S.K., Zhu S. 1995. Speed of sound in seawater as a function of salinity, temperature and pressure. J. Acoust. Soc. Am. 97: 1732-1736. http://dx.doi.org/10.1121/1.413048

Zimmermann M., Wilkins M.E., Weinberg K.L., Lauth R.R., Shaw F.R. 2003. Influence of improved performance monitoring on the consistency of a bottom trawl survey. ICES J. Mar. Sci. 60: 818-826. http://dx.doi.org/10.1016/S1054-3139(03)00043-2 
142 - Brčić et al.

Annex 1. - Equations for calculating speed of sound in seawater.

Equations for calculating speed of sound according to Del Grosso (1974) (see coeficients in Table 3).

$c(S, T, P)=C_{000}+\Delta C_{T}(T)+\Delta C_{S}(S)+\Delta C_{P}(P)+\Delta C_{S T P}(S, T, P)$

$\Delta C_{T}(T)=C_{T 1} T+C_{T 2} T^{2}+C_{T 3} T^{3}$

$\Delta C_{S}(S)=C_{S 1} S+C_{S 2} S^{2}$

$\Delta C_{P}(P)=C_{P 1} P+C_{P 2} P^{2}+C_{P 3} P^{3}$

$\Delta C_{S}(S, T, P)=C_{T P} T P+C_{T 3 P} T^{3} P+C_{T P 2} T P^{2}+C_{T 2 P 2} T^{2} P^{2}+$

$+C_{T P 3} T P^{3}+C_{S T} S T+C_{S T 2} S T^{2}+C_{S T P} S T P+C_{S 2 T P} S^{2} T P+C_{S 2 P 2} S^{2} P^{2}$

Equations for the conversion of depth into pressure according to Leroy and Parthiot (1998):

$P(Z, \Phi)=h(Z, \Phi)-h_{0} Z$

$P(Z, \Phi)=h(Z, 45) \times k(Z, \Phi)$

$h(Z, 45)=1.00818 \times 10^{-2} Z+2.465 \times 10^{-8} Z^{2}-1.25 \times 10^{-13} Z^{3}+2.8 \times 10^{-19} Z^{4}$

$k(Z, \Phi)=\frac{g(\Phi)-2 \times 10^{-5} Z}{9.80612-2 \times 10^{-5} Z}$

$g(\Phi)=9.7803\left(1+5.3 \times 10^{-3} \sin ^{2} \Phi\right)$

where $Z$ is the depth in metres, $\Phi$ the latitude in radians, and $h$ the pressure in MPa (relative to the atmospheric pressure). Since $h(Z, \Phi)$ is valid for oceanographers as the standard ocean (an ideal medium with a temperature of $0^{\circ} \mathrm{C}$ and salinity of 35), for the Mediterranean Sea the corrective term:

$h_{0} Z=-8.5 \times 10^{-6} Z+1.4 \times 10^{-9} Z^{2}$

must be subtracted from the value $h(Z, \Phi)$. Correction values for other seas can be found in Leroy and Parthiot (1998).
Table 3. - Coefficients used in Equations 1.1 to 1.4 .

\begin{tabular}{cc}
\hline Coefficient & Value \\
\hline$C_{000}$ & 1402.392 \\
$C_{T 1}$ & 5.012285 \\
$C_{T 2}$ & -0.0551184 \\
$C_{T 3}$ & 0.000221649 \\
$C_{S 1}$ & 1.32953 \\
$C_{S 2}$ & 0.0001288598 \\
$C_{P 1}$ & 0.1560592 \\
$C_{P 2}$ & 0.00002449993 \\
$C_{P 3}$ & -0.000000008833959 \\
$C_{S T}$ & -0.01275936 \\
$C_{T P}$ & 0.006353509 \\
$C_{T 2 P 2}$ & 0.00000002656174 \\
$C_{T P 2}$ & -0.000001593895 \\
$C_{T P 3}$ & 0.0000000005222483 \\
$C_{T 3 P}$ & -0.0000004383615 \\
$C_{S 2 P 2}$ & -0.000000001616745 \\
$C_{S T 2}$ & 0.00009688441 \\
$C_{S 2 T P}$ & 0.000004857614 \\
$C_{S T P}$ & -0.0003406824 \\
\hline
\end{tabular}

